\title{
Influence of Alteration in Far-Off Period Feeding Management on Water Intake, Water and Dry Matter Efficiency, Relative Immunoglobulin Level in Dairy Cows at Tropical Climate
}

\author{
Amit Kumar Singh $^{1 *}$, Champak Bhakat ${ }^{1}$, Anupam Chatterjee ${ }^{2}$ and Muthupalani Karunakaran ${ }^{3}$ \\ ${ }^{1}$ Livestock Production Management Section, ICAR-National Dairy Research Institute, Eastern Regional Station, Kalyani, INDIA \\ ${ }^{2}$ Animal Nutrition Section, ICAR- National Dairy Research Institute, Eastern Regional Station, Kalyani, INDIA \\ ${ }^{3}$ Animal Reproduction Section, ICAR- National Dairy Research Institute, Eastern Regional Station, Kalyani, INDIA
}

"Corresponding author: AK Singh; E-mail: amitkumarsingh5496@gmail.com

Received: 07 Aug., 2020

Revised: 19 Sept., 2020

Accepted: 15 Oct., 2020

\begin{abstract}
Proper changes in feeding management during dry period in periparturient dairy cows have shown better performances in terms of health, production, and dry matter intake. A study was performed on 14 healthy Jersey crossbred dairy cows which were separated into two groups viz. treatment and control group. Alteration in feeding management was done during far off period in treatment group than control group cows however, the cows of both the groups received similar feeding regimes in close up period as per the standard farm management practices. The statistically analyzed data revealed significantly higher $(\mathrm{P}<0.001)$ water intake, ratio of water to dry matter intake in treatment group animals as compared to that of control group cows. Data revealed numerically higher blood plasma Brix \% in treatment group animals however, there was significantly no difference $(\mathrm{P}>0.05)$ among treatment and the control group animals. Correlation coefficients suggested positive and high correlation $(\mathrm{P}<0.01)$ among water intake, dry mater intake, and milk yield and udder health status of dairy cows. In conclusion, based on this study it can be stated that the alteration in far-off period may be suitable for increased water intake, thereby increasing dry matter intake, reducing negative energy balance of dairy cows. It can be stated that proper reduction of concentrate supply during far-off dry period may be done to achieve improved performance of dairy cows in tropical region.
\end{abstract}

\section{HIGHLIGHTS}

(- Alteration in far-off period diet significantly affects water intake and dry matter intake

( Immunity levels are not compromised with alteration in far-off period diet

O Reduced negative energy balance can be achieved in dairy cows by altering far-off period diet in dairy animals

Keywords: Alteration, Dairy cows, Far-off period, Relative immunoglobulin, Water intake

India enjoys the presence of world's highest livestock population and milk production (FAO, 2016). There is continuous increase in the number of crossbred cows in Indian livestock population (BAHS, 2020) with an increase in demand of improved quality and more quantity of milk (Singh et al., 2020a). Superior genetics, advanced management strategies have helped in achieving this target (Capper et al., 2009). However, tropical climate offers harsh conditions for dairy animals (Singh et al., 2020b). Maintaining good quality milk with proper udder health, body condition and immunity level is still a challenge for the dairy farmers of this region (Singh et al., 2020c). Improved immunity levels are expected to enhance udder health and production performance of dairy cows (Sordillo, 2015; Singh et al., 2020a). Improved quality and quantity milk is beneficial for dairy owners as well as

How to cite this article: Singh, A.K., Bhakat, C., Chatterjee, A. and Karunakaran, M. (2020). Influence of alteration in far-off period feeding management on water intake, water and dry matter efficiency, relative immunoglobulin level in dairy cows at tropical climate. J. Anim. Res. 10(5): 741-749.

Source of Support: None; Conflict of Interest: None 
dairy industry (Alhussien and Dang 2018; Kumari et al., 2019; Kansal et al., 2020). Adoption of good management practices becomes important to achieve desired results from dairy animals (Kumari et al., 2020).

Improved management during transition period of dairy cows has shown improved performance of dairy cows in terms of production (Singh et al., 2020a), reproduction (Drackley et al., 2005), health and reduced energy balance (Overton and Waldron, 2004). It has been studied in important studies that increased forage and comparatively reduced concentrate intake during far-off period than closeup period shown improved results (Drackley et al., 2005; Beever, 2006; Roche et al., 2013; Roche et al., 2016; Singh et al., 2020a). There was significantly enhanced health and production performance of dairy cows (Roche et al., 2016; Singh et al., 2020a). There is a common trend of reduction in dry matter intake (DMI) during peri-partum period (Singh et al., 2020d) which leads to increased depletion of body reserves and hence leads to negative energy balance (nEB) (Roche et al., 2013; Drackley and Cardoso, 2014; Singh et al., 2020a). Increased nEB in dairy cows have shown sharp decline in body condition of dairy cows, poor milk performance and udder health status (Berry et al., 2007; Bhakat et al., 2017; Alhussien and Dang, 2018; Singh et al., 2020d; Singh et al., 2020g). Reduced nEB in dairy animals has shown increased cases of post-partum anoestrus and other reproductive problems (Overton and Waldron, 2004). High nEB leads to immunosuppression during transition period which may lead to a potential risk for impairment of mammary function of dairy cows thereby reduced udder health status may take place which ultimately causes poor quality milk in dairy cows (Berry et al., 2007). Dairy cows which had improved dry matter in peripartum period, they had better health and production and reduced $\mathrm{nEB}$ during transition and initial lactation period (Roche et al., 2013; Drackley and Cardoso, 2014; Singh et al., 2020a) than the cows which were observed with lower DMI during peripartum period. Hence, the management strategy for dairy cows should be taken into such a way that it promotes DMI and reduced $\mathrm{nEB}$ during peripartum period (Singh et al., 2020a; Soulat et al., 2020). In a latest study it was indicated that enhanced water intake leads to improved dry matter intake and hence the overall performance of dairy cows (Axegard, 2017; Singh et al., 2020e).
The above discussed points formed the basis of this study. To our knowledge, no study is present which investigates the effect of reducing concentrate intake during far-off period on water intake, water efficiency, immunoglobulin levels and their relationship with different health and production of dairy cows. Therefore, this study was meticulously framed to analyze the effect of alteration of dry period feeding regimes of dairy cows i.e. reducing concentrate intake of dairy cows during far-off period to investigate its effect on water intake, some water and feed efficiency ratios, immunoglobulin status and eventually their effect on dry matter intake $\mathrm{nEB}$, blood protein, glucose, urea, body weight of dairy cows.

\section{MATERIALS AND METHODS}

\section{Location of the study}

This study was conducted in the organized dairy farm of Indian council of Agricultural Research (ICAR)- National Dairy Research Institute, Eastern Regional Station, Kalyani (tropical Gangetic region), West Bengal, India. City of Kalyani is situated $15 \mathrm{~m}$ above the mean sea level offering a hot and humid climatic condition. The monthly average temperature is approximately in the range of 19.2 ${ }^{\circ} \mathrm{C}$ to $30.5^{\circ} \mathrm{C}$ and overall $26.3^{\circ} \mathrm{C}$ in Kalyani. May is the warmest (averages $30.5^{\circ} \mathrm{C}$ ) month and December being the coldest $\left(19.2^{\circ} \mathrm{C}\right)$ month of the year. Overall of about 1345 $\mathrm{mm}$ precipitation is found annually. The range of average rainfall is from as low as $2 \mathrm{~mm}$ in December to $275 \mathrm{~mm}$ in the month of September. Geographical coordinates being $22^{\circ} 58^{\prime} 30^{\prime \prime} \mathrm{N} 88^{\circ} 26^{\prime} 04^{\prime \prime} \mathrm{E}$.

\section{Animals for experimentation}

This experimentation was conducted during the year 2018 to 2019 on fourteen apparently healthy Jersey crossbred cow having almost similar age groups, body weight, BCS, parity, and production levels which were divided into 2 comparable groups i.e. group- $1(\mathrm{n}=7)$ as treatment and group-2 $(n=7)$ as control. After an adaptation period the final observation was taken during whole dry period (60 days pre calving), which continued during at calving and post-partum (period) up to 120 days of lactation period. 


\section{Feeding management}

Every cow of treatment group was provided with $2 \mathrm{~kg} / \mathrm{day} /$ animal during far-off period ( 1 to 45 days) as compared to control group cows who received $3 \mathrm{~kg}$ /day /animal of concentrates during same period. Both groups during close up (to calving) period (46 to 60 days) and postpartum period received same amount of concentrates as per the standard farm management practices. Ad libitum green and dry fodders (70:30) were provided to both groups during dry period as well as postpartum period as per the standard farm management practices (NRC standards).

Dairy cows were provided with good quality green fodders consisting freshly chopped green Maize, Sorghum, Napier grass during summer and autumn season, Barseem, Lucerne, Oats, Mustard in winter season. Wheat straw and paddy straw were utilized as dry fodders. Thus, cows of treatment group consumed high fiber and low energy diet than control group cows during far off dry period. The DCP and TDN contents were $14 \%$ and $68 \%$ respectively. Same concentrate mixture as per the Bureau of Indian Standards type II concentrate mixture (BIS 2052:2009) for feeding cattle was included in diet of each group cows.

\section{Housing management}

Each animal was kept under separate stall fed housing conditions with proper manger and watering facility with proper ventilation facility (Singh et al., 2020b; Singh et al., 2020e). Floor in animal house was made of paved concrete type however separate paddy materials were provided for cushioning near parturition period to avoid any physical injury (Mishra et al., 2017; Singh et al., 2020f). Trained veterinary person was allotted for regular health check of dairy cows. Weaning at birth was followed in both the groups. Both group animals were provided same housing management strategies.

\section{Collection of data}

Data collection for water intake, DMI, Brix \% parameters was done during morning hours after milking and before offering any kind of feed or water. After the collection of required data for different parameters, the animals were provided with feeding and watering facility as per the standards farm management practices.

\section{Water intake}

Fresh and clean water was always provided to the dairy cows. Hardness of water ranged in between 200- $220 \mathrm{mg} / 1$ of $\mathrm{CaCO}_{3}$, which is stated as acceptable to cattle (Adams and Sharpe, 1995), along with $\mathrm{pH}$ range from 7.3 to 7.71 with water temperature 23.1 to $26.3^{\circ} \mathrm{C}$ was offered to the cows during their 60 days dry period with the help 15 liters capacity of aluminum buckets. Cows were offered ad libitum water and left untouched for about 30 minutes each time to every cow to have as much water as they wanted to drink thrice a day during 8-9 AM, 1-2 PM, 7-9 PM daily. However, water was measured every time using an electronic weighing balance, with a least count of 50 $\mathrm{g}$ before and after offering to the cows to determine the actual amount of water intake by experimental animals. The watering operation was ensured to be completely individual without the interference of other cows.

\section{Dry matter intake}

During dry period animal's feed intake (individual feeding) of concentrate mixture and fodder (green \& dry) was measured every day with the help of an electronic weighing balance with a least count of $50 \mathrm{~g}$. DMI through concentrate and fodder (green+dry) was estimated daily during dry period. Dry matter in the composite mixture sample of fodders was carried out by drying at $38^{\circ} \mathrm{C}$ for 48 hours in hot air oven. This dry matter was added to the dry matter of concentrate mixture to obtain total dry matter intake through concentrate and fodder. This made the estimation of total DMI (TDMI).

\section{Important water and feed efficiency ratios}

Ratio water and average daily gain or water intake per unit average daily gain (WIPDG), ratio of water to DMI or water intake per kg DMI (WIPMI), ratio of average daily gain to DMI (DGPDM) of dairy animals under both the groups were calculated as under for total dry period of 60 days.

$$
\begin{aligned}
& \mathrm{WIPDG}=\mathrm{WI} / \mathrm{ADG} \\
& \mathrm{WIPMI}=\mathrm{WI} / \mathrm{DMI} \\
& \mathrm{DMGDG}=\mathrm{DMI} / \mathrm{ADG}
\end{aligned}
$$

Where, WIPDG = one of the parameters for water 
efficiency; DMGDG = one of the parameters for feed efficiency; $\mathrm{WI}=$ water intake; $\mathrm{ADG}=$ average daily gain (calculated by the difference of average weight gained during dry period and initial body weight of dairy cows); $\mathrm{DMI}=$ dry matter intake

\section{Collection of blood plasma}

From each cows of both the group, about $10 \mathrm{ml}$ blood samples were collected aseptically from jugular vein of individual cows at an intervals of 60 day pre-calving, 30 days pre-calving, at calving, and post calving period at 30 days, 60 days and 90 days. Aseptic blood collection tubes having $2 \%$ EDTA as an anticoagulant were used to collect the blood samples followed by which plasma was separated out using centrifuging machine. This plasma was utilized for estimation of Brix \%. Cows were properly secured before collection of blood samples by an experienced animal handler to assure that the cows are under least stress during whole collection period.

\section{Brix \%}

Brix \% was used to determine the relative immunoglobulin levels in plasma of dairy cows. Neumann \& Miller's (Model- NM-0-18Brix) was utilized for estimating relative immunoglobulin level in dairy animals of this study. A drop of plasma was put over the film of Brix refractometer to read the Brix\% values. Every time the Brix film was wiped with fresh cotton plug to avoid the overlapping of reading of different samples. Instructions for the usage of Brix refractometer were carefully followed.

\section{Correlation of different parameters}

Data of different parameters such as water intake, TDMI, WIPDG, WIPMI, DMPDG, Brix\%; plasma non-esterified fatty acid (NEFA) for estimating energy balance, glucose, urea, total protein in plasma; DMI, BW of dairy cows was utilized for analyzing correlation coefficients.

\section{STATISTICAL ANALYSIS}

Each and every parameters of this study was meticulously analyzed using IBM SPSS statistics 22 software package. Pearson's square coefficients were utilized for bringing out the correlation of water intake, Brix $\%$ with milk production, quality, composition, udder health, blood parameters and BCS parameters of dairy cows at tropical lower Gangetic region.

\section{RESULTS AND DISCUSSION}

\section{Water intake (kg)}

Estimation of water intake is important way to enhance the efficiency of measuring other farm activities (Singh et al., 2020e). Water intake during dry period of two different groups has been presented in Fig. 1 of this article.

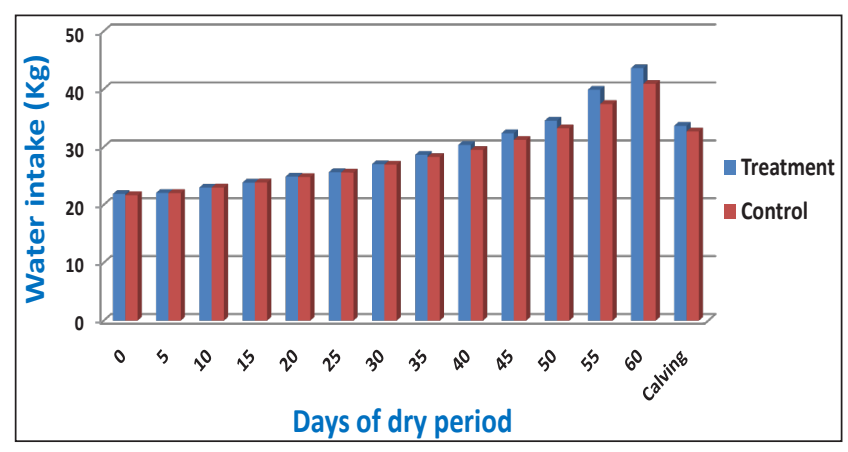

Fig. 1: Prepartum water intake (kg/day) in dairy animals at hothumid climate

Stringent statistical analysis for an interval of 5 days for whole dry period expressed that water intake in dairy cows of treatment group was significantly higher $(\mathrm{P}<0.01)$ than that of control group animals. Initially the water intake in both the group animals were statistically similar $(\mathrm{P}>0.05)$ however after 10 days interval of dry period, the treatment group animals had significantly higher intake during overall dry period. Water intake in both the groups increased as the dry period progressed. However, on the day of calving, there was a sharp decline in water intake in both the group animals. Highest water intake by dairy cows in both the group was seen in the last week of dry period. Highest water intake by individual cow was $47.4 \mathrm{~kg} /$ day and lowest was $20.65 \mathrm{~kg} /$ day respectively. This decline may be due to parturition stress experienced by the cows. Increased water intake may lead to increased dry matter intake and thereby enhancing the productive performance of dairy cows during initial lactation period (Axegard, 2017; Singh et al., 2020e). Findings of this study are in agreement with Holter and Urban (1992) who observed 
that during dry period dairy cows require $15-61$ ltr/day and Khelil-Arfa et al. (2012) reported that dairy cows consumed water $2.3-140 \mathrm{~kg}$ /day during their dry period. More body weight of animal may lead to higher water intake (Meyer et al., 2004) whereas reduced body was associated in restricted water availability for dairy animals (Burgos et al., 2001). Major factors which influence daily free WI of dairy cows include DMI, dry matter content of feed, milk yield, minimum ambient temperature and sodium intake (Murphy et al., 1983; Cardot et al., 2008; Singh et al., 2020e). Filho et al. (2004) stated that cows have more preference for large troughs. However, unpleasant source of water may decrease the acceptance by cows and they may drink lesser than their requirement to meet different physiological needs (Beede, 2006). However Appuhamy et al. (2016) proposed a model which worked without the estimation of DMI measurement, for estimating water intake due to absence or inconsistency of DMI measurement accuracy.

\section{Water and feed efficiency ratios}

This is the first study which deals with the estimation of efficiency parameters of water and feed intake in dairy cows after subjecting the control group animals to reduced supply of concentrate during far-off period than close-up period feeding regimes.

\section{WI: DMI and DMI: ADG}

Fig. 2 represents the changes in WI: DMI during dry period of dairy cows under tropical climate. Meticulous statistical analysis revealed significantly higher $(\mathrm{P}<0.01)$ WI: DMI in treatment group animals than control group animals. Significantly higher water intake in treatment group animals than control group may be the reason for higher WI: DMI. Observations of this investigation are in line with the findings of Holter and Urban (1992), Kume et al. (2010), Khelil-Arfa et al. (2012), and Axegard (2017), Ahlberg et al. (2019) who remarked positive association of water intake and dry matter intake in dairy cows.

Ratio of DMI to ADG is depicted in Fig. 3 of this study paper. Statistical analysis showed that significantly higher $(\mathrm{P}<0.001)$ ratio was observed in treatment group animals than control group cows. This study revealed that treatment group received reduced concentrate supply during far-off period showed overall increased DMI and also the efficiency of DMI in dairy cows.

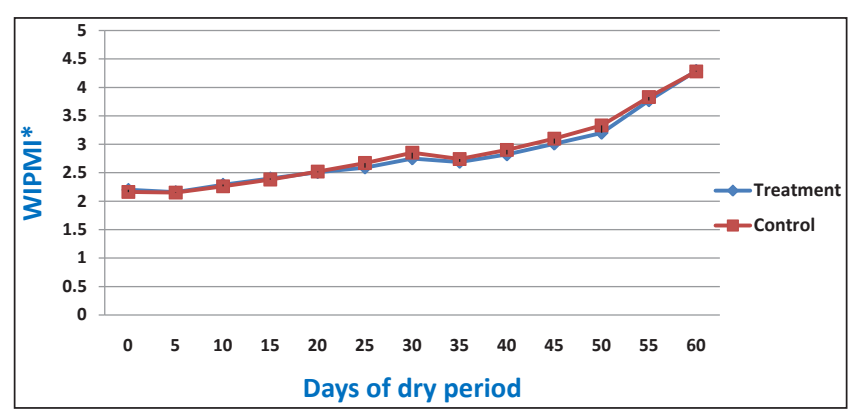

Fig. 2: Changes in water intake to per unit DMI consumption in Jersey crossbred cows at tropical climate

$* \mathrm{WIPMI}=\mathrm{WI} / \mathrm{TDMI}$

The reason behind this may be due to the lower consumption of concentrate intake influenced more fodder intake to satisfy its appetite than that of control group animals which consumed more concentrate and thereof had lower fodder intake by dairy cows during whole dry period of this study. Findings of this study are corroborated with the observations of Berry and Crowley (2013) and Ahlberg et al. (2019) who expressed that ratio of DMI to ADG is one of the measurements of feed efficiency in dairy animals.

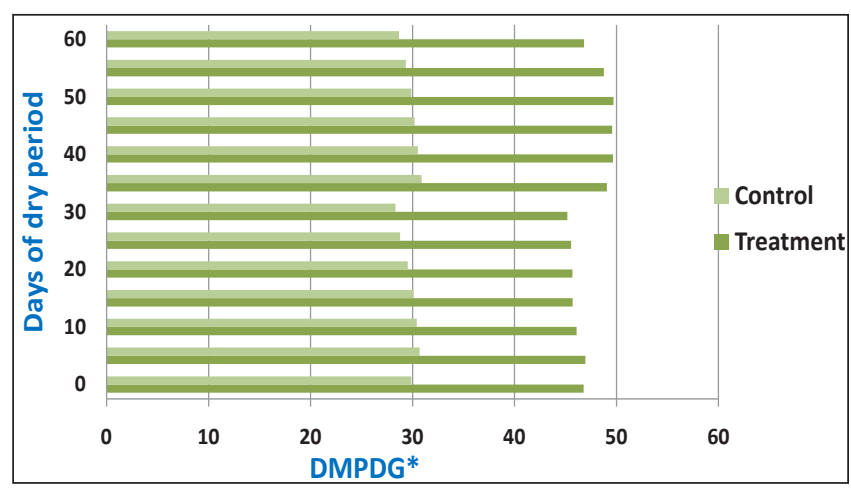

Fig. 3: Changes in the ratio of dry matter intake to the average daily gain in dairy cows under hot- humid climate

*DMPDG $=$ DMI/ADG

\section{Brix \% for relative immunoglobulin level}

Table 1 shows the least square means of Brix \% with standard errors of blood plasma immunoglobulin level of dairy cows of two different group animals. This study 
showed on statistical analysis that there was significantly no difference $(\mathrm{P}>0.05)$ among the relative immunoglobulin level of dairy cows during whole dry period and during 3 months of lactation period.

Table 1: LSQ mean \pm S.E. of blood plasma Brix $\%$ in different groups of Jersey crossbred cows under tropical climate

\begin{tabular}{lll}
\hline Months $(M)$ & Treatment group & Control group \\
\hline 0 (before DP) & $10.53^{\mathrm{a}} \pm 0.28$ & $10.47^{\mathrm{a}} \pm 0.10$ \\
$1^{\text {st }} \mathrm{M}$ of DP & $10.01 \pm 0.02$ & $9.97 \pm 0.27$ \\
$2^{\text {nd }} \mathrm{M}$ of DP & $10.20 \pm 0.26$ & $10.18 \pm 0.27$ \\
Overall DP & $10.11^{\mathrm{a}} \pm 0.14$ & $10.07^{\mathrm{a}} \pm 0.19$ \\
$1^{\text {st }} \mathrm{M}$ of LP & $9.67 \pm 0.21$ & $9.97 \pm 0.20$ \\
$2^{\text {nd }} \mathrm{M}$ of LP & $10.67 \pm 0.52$ & $10.55 \pm 0.19$ \\
$3^{\text {rd }} \mathrm{M}$ of LP & $10.35 \pm 0.29$ & $10.50 \pm 0.16$ \\
Overall LP & $10.23^{\mathrm{a}} \pm 0.18$ & $10.34^{\mathrm{a}} \pm 0.12$ \\
\hline
\end{tabular}

Means bearing different superscripts differ significantly $(\mathrm{P}<0.05)$.

It is clear from this study that reduction in concentrate supply to dairy cows during far-off period than close-up period does not alter immunoglobulin level during whole dry period followed by 3 months of lactation period. Different researchers (Morrill et al., 2013; Deelen et al., 2014; Elsohaby et al., 2015) have utilized Brix refractometer for estimating serum immunoglobulin levels in dairy calves with sensitivity of 86 to $90 \%$ and specificity of 83 to $94 \%$. They considered Brix refractometer suitable for estimating relative serum $\mathrm{IgG}$ from $<4$ to $>45 \mathrm{~g} / \mathrm{L}$ with correlation coefficients of $0.87,0.93$ and 0.79 respectively. Deelen et al. (2014) proposed that digital Brix refractometry may be convenient and economical for dairy producers to estimate IgG concentration.

\section{Correlation of different parameters}

Details of Pearson's and Spearman's correlation coefficients for different parameters have been shown in table 2 of this manuscript. The high and positive correlation of WI and DMI may be due to high mutual dependency on body weight of dairy animals due to unknown mechanism which exists between WI and DMI (Bachmanov et al., 2002). A linear and significant relationship exists between WI and DMI $(\mathrm{P}<0.05)$ of this study similar to the finding of Ahlberg et al. (2019). Spearman correlations were higher than Pearson correlations between WI and DMI/ ADG ratio which indicated that there was less re-ranking when WI was getting changed among the animals for feed efficiency traits. Animals whose WI was less, they were found to consume lower DMI. Hence, significantly less DMI was consumed by the dairy animals of control group. There was highly significant $(\mathrm{P}<0.01)$ correlation between the ratios of DMI/ADG and WI/ADG which could be

Table 2: Pearson's below diagonal and Spearman's above diagonal correlation coefficient for different performances of dairy cows at tropical climate

\begin{tabular}{|c|c|c|c|c|c|c|c|c|c|c|c|}
\hline & Brix & WI & DMI & WIPMI & WIPDG & DMPDG & BW & NEFA & B.Glu & B.Ur & B.Pr \\
\hline Brix & & -.30 & .14 & -.35 & .09 & .23 & -.32 & -.23 & -.05 & -.32 & .05 \\
\hline WI & -.22 & & .16 & $.93 * *$ & $.54^{* *}$ & .13 & .02 & .12 & -.18 & .02 & .11 \\
\hline DMI & -.07 & $.48^{*}$ & & -.16 & $.64^{* *}$ & $.95^{* *}$ & -.32 & .32 & $-.95 * *$ & -.32 & $.85^{* *}$ \\
\hline WIPMI & -.22 & $.94 * *$ & .14 & & .33 & -.18 & .12 & .02 & .13 & .12 & -.18 \\
\hline WIPDG & .17 & $.42 *$ & $.78^{* *}$ & .16 & & $.79 * *$ & $-.76^{* *}$ & -.36 & $-.42 *$ & $-.76^{* *}$ & $.66^{* *}$ \\
\hline DMPDG & -.25 & -.08 & $-.68 * *$ & .19 & $-.94 * *$ & & $-.60 * *$ & .00 & $-.80 * *$ & $-.60 * *$ & $.88 * *$ \\
\hline BW & -.23 & -.03 & -.23 & .06 & $-.74 * *$ & $-.79 * *$ & & .80 ** & .00 & $1.00 * *$ & $-.46^{*}$ \\
\hline NEFA & -.15 & .09 & .32 & -.03 & -.24 & -.28 & $.81 * *$ & & $-.60 * *$ & $.80 * *$ & .08 \\
\hline B.Glu & .05 & -.29 & $-.86^{* *}$ & .02 & $-.47 *$ & $-.43^{*}$ & -.20 & $-.73 * *$ & & .00 & .08 \\
\hline B.Ur & -.30 & .15 & -.05 & .19 & $-.62 * *$ & $-.71 * *$ & $.97 * *$ & $.85^{* *}$ & -.33 & & $-.75^{* *}$ \\
\hline B.Pr & .13 & -.07 & $.68 * *$ & -.38 & $.59 * *$ & $.67 * *$ & -.17 & .36 & $-.75 * *$ & -.14 & \\
\hline
\end{tabular}

$\mathrm{BW}=$ body weight; $\mathrm{B} . \mathrm{Glu}=$ blood plasma glucose; $\mathrm{B} . \mathrm{Ur}=$ blood plasma urea; $\mathrm{B} . \mathrm{Pr}=$ blood plasma total protein; *Correlation is significant at the 0.05 level (2-tailed); $* *$ Correlation is significant at the 0.01 level (2-tailed) 
due to significantly high DMI and WI during whole dry period (Pearson's $\mathrm{P}=0.78$ and Spearman's $\mathrm{P}=0.79$ ). The investigations of this study are in line with the findings of (Arthur et al., 2001; Basarab et al., 2003; Nkrumah et al., 2007; Berry and Crowley, 2013; Ahlberg et al., 2019).

BW was significantly $(\mathrm{P}<0.01)$ associated with NEFA, plasma glucose, urea, protein values in this studies. From phenotypic correlations it can be stated that BW affects energy balance. Blood glucose and protein may be higher when the cows have more BW due to the presence of more energy reserves in dairy animals. Plasma protein could have been more due to more protein deposition in the body of dairy animals. In this study there was an agreement between and Pearson's and Spearman's correlation coefficients. However, BW was negatively and significantly $(\mathrm{P}<0.01)$ corroborated with water and feed efficiency measures. NEFA was significantly $(\mathrm{P}<0.01)$ and negative correlation with plasma glucose level in this study which suggested that glucose content of plasma gets lowered when there is negative energy balance as reflected by higher NEFA values in dairy cows. However, blood urea was significantly $(\mathrm{P}<0.01)$ and positively correlated with NEFA values. Negative energy balance is shown by elevated urea levels in blood (Cheng et al., 2015). Blood protein, glucose level was and negatively corroborated with DMI and water efficiency measure of this study $(\mathrm{P}<0.05$ and $\mathrm{P}<0.01)$ respectively. However, positive and significant correlation $(\mathrm{P}<0.01)$ was noticed for blood protein levels with dry mater and water efficiency of dairy animals in this study.

There was little positive but non-significant correlation of Brix \% with plasma glucose, protein and water efficiency parameter of this study. However, a non-significant and negative correlation was observed between Brix \% and blood urea, NEFA levels, BW, DMI and dry matter efficiency ratios of this study.

\section{CONCLUSION}

This study has revealed relatively newer aspect of alteration of dry period feeding management practice for dairy cows in tropical region. Statistically, the results shown significantly higher water intake in treatment group animals. Efficiency parameters for water and dry matter intake showed significantly better performance in treatment group cows than control group animals of this study. This study revealed for the first time that reduction in concentrate supply during far-off period as compared to close-up period leads to enhancement in the production performance, reduced negative energy balance, and body condition of dairy cows without altering their relative immunoglobulin levels during dry period. In conclusion, it can be stated that reduction in concentrate supply during far-off period than close-up period may have beneficial effects in crossbred dairy cows of tropical region.

\section{ACKNOWLEDGEMENTS}

Authors have sincere gratitude towards the Director of Indian Council of Agricultural Research- National Dairy Research Institute, Karnal, India and Head of Eastern Regional Station of ICAR- National Dairy Research Institute, Kalyani, West Bengal, India for providing financial assistance and other necessary facilities for the completion of this study.

\section{REFERENCES}

Adams, R.S. and Sharpe, W.E. 1995. Water intake and quality for dairy cattle. Penn State Extension Publication DAS 95-8, University Park, PA.

Alhussien, M.N. and Dang, A.K. 2018. Milk somatic cells, factors influencing their release, future prospects and practical utility in dairy animals: An overview. Vet. World, 11(5): 562-577.

Appuhamy, J.A.D.R.N., Judy, J.V., Kebreab, E. and Kononoff, P.J. 2016. Prediction of drinking water intake by dairy cows. J. Dairy Sci., 91(9): 1-15.

Arthur, P.F., Archer, J.A., Johnston, D.J., Herd, R.M., Richardson, E.C. and Parnell, P.F. 2001. Genetic and phenotypic variance and covariance components for feed intake, feed efficiency, and other postweaning traits in Angus cattle. J. Anim. Sci., 79: $2805-2811$.

Axegard, C. 2017. Individual drinking water intake of dairy cows in anAMS barn. Degree project in Animal Science Submitted to Swedish University of Agricultural Sciences. Retrieved from http://urn.kb.se/resolve?urn=urn:nbn:se:slu:epsilon-s-6462 (Access date: April 27, 2019).

Bachmanov, A.A., Reed, D.R., Beauchamp, G.K. and Tordoff, M.G. 2002. Food intake, water intake, and drinking spout side preference of 28 mouse strains. Behav. Genet., 32: 435-443.

Basarab, J.A., Price, M.A., Aalhus, J.L., Okine, E.K., Snelling, W.M. and Lyle, K.L. 2003. Residual feed intake and body composition in you growing cattle. Can. J. Anim. Sci., 83(2): 189-204. 
Basic Animal Husbandry Statistics (BAHS). 2020. Basic Animal Husbandry Statistics published by Department of Animal Husbandry \& Dairying, Government of India. Accessed at http://www.dahd.nic.in/documents/reports (25 th June, 2020).

Beede, D.K. 2006. Evaluation of water quality and nutrition for dairy cattle. ( red.), High plains dairy conference. (ss. 129154) Albuquerque, NM.

Beever, D.E. 2006. The impact of controlled nutrition during the dry period on dairy cow health, fertility and performance. Anim. Reprod. Sci., 96(3): 212-226.

Berry, D.P. and Crowley, J.J. 2013. Cell biology symposium: genetics of feed efficiency in dairy and beef cattle. J. Anim. Sci., 91: 1594-1613.

Berry, D.P., Macdonald, K.A., Stafford, K., Matthews, L. and Roche, J.R. 2007. Associations between body condition score, body weight and somatic cell count and clinical mastitis in seasonally calving dairy cattle. J. Dairy Sci., 90(2): 637-648.

Bhakat, C., Chatterjee, A., Mandal, A., Mandal, D.K., Karunakaran, M. and Dutta, T.K. 2017. Effect of cleanliness and hygiene on occurrence of mastitis in crossbred cows in West Bengal. Life Sci. Int. Res. J., 4(1): 10 -14.

Burgos, M., Senn, M., Sutter, F., Kreuzer, M. and Langhans, W. 2001. Effect of water restriction on feeding and metabolism in dairy cows. Am. J. Physiol. Regul. Integr. Comp. Physiol., 280(2): R418-R427.

Capper, J.L., Cady, R.A. and Bauman, D.E. 2009. The environmental impact of dairy production: 1944 compared with 2007. J. Anim. Sci., 87(6): 2160-2167.

Cardot, V., Le Roux, Y. and Jurjanz, S. 2008. Drinking behavior of lactating dairy cows and prediction of their water intake. $J$. Dairy Sci., 91: 2257-2264.

Cheng, Z., Oguejiofor, C.F., Swangchan-Uthai, T., Carr, S. and Wathes, D.C. 2015. Relationships between circulating urea concentrations and endometrial function in postpartum dairy cows. Animals, 5(3):748-773.

Deelen, S, Ollivett, T., Haines, D. and Leslie, K. 2014. Evaluation of a Brix refractometer to estimate serum immunoglobulin G concentration in neonatal dairy calves. J. Dairy Sci., 97: $3838-3844$.

Drackley, J.K. and Cardoso, F.C. 2014. Prepartum and postpartum nutritional management to optimize fertility in high-yielding dairy cows in confined TMR systems. Animal, 8(1): 5-14.

Drackley, J.K., Dann, H.M., Douglas, G.N., Guretzky, N.A.J., Litherland, N.B., Underwood, J.P. and Loor, J.J. 2005. Physiological and pathological adaptations in dairy cows that may increase suseptibility to periparturient diseases and disorders. Ital. J. Anim. Sci., 4(4): 323-344.
Elsohaby, I., McClure, J.T. and Keefe, G.P. 2015. Evaluation of digital and optical refractometers for assessing failure of transfer of passive immunity in dairy calves. J. Vet. Int. Med., 29: 721-726.

Filho, L.C.P.M. 2004. Designing better water troughs: dairy cows prefer and drink more from larger troughs. Appl. Anim. Behav. Sci., 89: 185-193.

Food and Agriculte Organization (FAO). 2016. FAO in India: India at a glance. Accessed at http://www.fao.org/india/faoin-india/india-at-a-glance/ar/ (25 $5^{\text {th }}$ June, 2020).

Holter, J. and Urban, W. 1992. Water partitioning and intake prediction in dry and lactating Holstein cows. J. Dairy Sci., 75: 1472-1479.

Kansal, G., Yadav, D.K., Singh, A.K. and Rajput, M.S. 2020. Advances in the management of bovine mastitis. Int. J. Adv. Agric. Sci. Tech., 7(2): 10-22.

Khelil-Arfa, H., Boudon, A., Maxin, G. and Faverdin, P. 2012. Prediction of water intake and excretion flows in Holstein dairy cows under thermoneutral conditions. Animal, 6(10): 1662-1676.

Kumari, T., Bhakat, C. and Singh, A.K. 2020. Adoption of management practices by the farmers to control sub clinical mastitis in dairy animals. J. Entomol. Zool. Stud., 8(2): 924927.

Kumari, T., Bhakat, C., Singh, A.K., Sahu, J., Mandal, D.K. and Choudhary, R.K. 2019. Low cost management practices to detect and control sub-clinical mastitis in dairy cattle. Int. J. Curr. Microbiol. Appl. Sci., 8(5): 1958-1964.

Kume, S., Nonaka, K., Oshita, T. and Kozakai, T. 2010. Evaluation of drinking water intake, feed water intake and total water intake in dry and lactating cow's fed silage. Livest. Sci., 128: 46-51.

Meyer, U., Everinghoff, M., Gädeken, D. and Flachowsky, G. 2004. Investigations on the water intake of lactating dairy cows. Livest. Prod. Sci., 90: 117-121.

Mishra, M., Upadhyay, D., Gurav, A. and Domple, V. 2017. Effect of floor on lameness in crossbred dairy Cow: A Review. Int. J. Livest. Res., 7(12): 22-40.

Morrill, K.M., Polo, J., Lago, A., Campbell, J., Quigley, J. and Tyler, H. 2013. Estimate of serum immunoglobulin G concentration using refractometry with or without caprylic acid fractionation. J. Dairy Sci., 96: 4535-4541.

Murphy, M., Davis, C. and McCoy, G. 1983. Factors affecting water consumption by Holstein cows in early lactation. $J$. Dairy Sci., 66: 35-38.

Nkrumah, J.D., Crews Jr. D.H., Basarab, J.A., Price, M.A., Okine, E.K., Wang, Z., Li, C. and Moore, S.S. 2007. Genetic and phenotypic relationships of feeding behavior and temperament with performance, feed efficiency, ultrasound, 
and carcass merit of beef cattle. J. Anim. Sci., 85(10): 23822390 .

Overton, T.R. and Waldron, M.R. 2004. Nutritional management of transition dairy cows: Strategies to optimize metabolic health. J. Dairy Sci., 87(E. Suppl.): E105-E119.

Roche, J.R., Heiser, A., Mitchell, M.D., Crookenden, M.A., Walker, C.G., Kay, J.K. and Meier, S. 2016. Strategies to gain body condition score in pasture-based dairy cows during late lactation and the far-off non lactating period and their interaction with close-up dry matter intake. J. Dairy Sci., 100(3): 1720-1738.

Roche, J.R., Macdonald, K.A., Schütz, K.E., Matthews, L.R., Verkerk, G.A., Meier, S. and Webster, J.R. 2013. Calving body condition score affects indicators of health in grazing dairy cows. J. Dairy Sci., 96(9): 5811-5825.

Singh, A.K., Bhakat, C., Kumari, T., Mandal, D.K., Chatterjee, A. and Dutta, T.K. 2020d. Influence of alteration of dry period feeding management on body weight and body measurements of Jersey crossbred cows at lower Gangetic region. J. Anim. Res., 10(1): 137-141.

Singh, A.K., Bhakat, C., Mandal, D.K., Mandal, A., Rai, S., Chatterjee, A. and Ghosh, M.K. 2020a. Effect of reducing energy intake during dry period on milk production, udder health and body condition score of Jersey crossbred cows at tropical lower Gangetic region. Trop. Anim. Health Pro., 52: 1759-1767.

Singh, A.K., Bhakat, C., Yadav, D.K., Kumari, T., Mandal, D.K., Rajput, M.S. and Bhatt, N. 2020c. Effect of pre and postpartum Alphatocopherol supplementation on body measurements and its relationship with body condition, milk yield, and udder health of Jersey crossbred cows at tropical lower Gangetic region. J. Entomol. Zool. Stud., 8(1): 14991502 .
Singh, A.K., Kumari, T., Rajput, M.S., Baishya, A., Bhatt, N. and Roy, S. 2020f. A review: effect of bedding material on production, reproduction and health and behavior of dairy animals. Int. J. Livest. Res., 10(7): 11-20.

Singh, A.K., Yadav, D.K., Bhatt, N., Sriranga, KR and Roy, S. 2020b. Housing management for dairy animals under Indian tropical type of climatic conditions-a review. Vet. Res. Int., 8(2): 94-99.

Singh, A.K., Bhakat, C., Yadav, D.K., Kansal, G. and Rajput, M.S. 2020e. Importance of measuring water intake in dairy animals: A Review. Int. J. Adv. Agric. Sci. Tech., 7(2): 23-30.

Singh, A.K., Bhakat, C., Kumari, T., Mandal, D.K., Chatterjee, A., Karunakaran, M. and Dutta, T.K. 2020g. Influence of pre and postpartum Alphatocopherol supplementation on milk yield, milk quality and udder health of Jersey crossbred cows at tropical lower Gangetic region. Vet. World, 13: 2006-2011.

Sordillo, L.M. 2015. Nutritional strategies to optimize dairy cattle immunity. J. Dairy Sci., 99: 4967-4982.

Soulat, J., Knapp, E., Moula, N., Hornick, J.L., Purnelle, C. and Dufrasne, I. 2020. Effect of dry-period diet on the performance and metabolism of dairy cows in early lactation. Published online Animals. 
